
August 1936

\title{
DISTRIBUTION OF COMPOUNDS IN PORTLAND CEMENT
}

\author{
By J. Arthur Swenson and E. P. Flint
}

\begin{abstract}
Thirteen cements have been separated into size-fractions by means of air elutriation and chemical analyses have been made on all of the fractions and the whole cements. The compound compositions were calculated according to the method of Bogue and plotted by two different methods so as to show how the compounds are distributed with respect to size of particles. Heats of solution and hydration were determined for the fractions of five cements which were of very similar chemical composition and yet were known to differ considerably in certain physical properties. Studies of the observed heats of solution of the fractions of these cements as compared with the calculated theoretical heats of solution indicated discrepancies between the true compositions and the calculated compositions. The results of microscopic examination of etched sections of the cement clinkers gave further indication of the existence of such discrepancies.
\end{abstract}

\section{CONTENTS}

I. Introduction

II. Variation of chemical composition with particle size

1. Description of ements... 202

2. Particle size and composition 262

III. Heats of hydration of size fractions

1. General details

2. Discussion of results

IV. Accuracy of calculated compound compositions as indicated by other methods _._.

1. Studies of heats of solution 272

V. Summary

2. Microscopic analyses..... 274

\section{INTRODUCTION}

Investigations at the National Bureau of Standards and elsewhere during the past several years have emphasized the heterogeneous nature of portland cement by showing that its chemical constituents are distributed unequally among the differently sized particles making up the cement. ${ }^{1}$ Recognition of the existence of these inequalities is important since they are sufficiently large in many cases to render futile any attempts at quantitative explanations of the behavior of the cement merely on the basis of the chemical analysis of the whole cement. The problem is further complicated by the fact that the

\footnotetext{
1 Report of Conservation Bureau and Research Laboratory, Portland Cement Association, Spring meeting of 1932 .

Rordam, Rock Products (July 30, 1932).

Carlson and Bates, Rock Products (Oct. 22, 1932)

Lerch and Bogue, J. Research NBS 12, 645 (1934) RP684.

Swenson, Wagner, and Pigman, J. Research NBS 14, 419 (1935) RP777.
} 
true compound compositions may differ considerably from the calculated compositions under certain conditions of clinker cooling. ${ }^{2}$ Data indicating the magnitude of both of these effects are presented in this paper.

\section{VARIATION OF CHEMICAL COMPOSITION WITH PARTICLE SIZE}

\section{DESCRIPTION OF CEMENTS}

Thirteen cements, representing products of six different manufacturers, were studied. Cements 1 to 4 in table 1 were produced at four different plants, 5 and 6 at one plant, and 7 to 13 at one plant. Cements $1,2,3,4,7$, and 8 are of the low-heat-of-hardening type, 5,6 , and 9 are of the rather high-heat-of-hardening type, while 10 , 11, 12 , and 13 are moderately low-heat-of-hardening cements. Complete milling information is not available, but it is known that cements 5 and 6 were ground in Hardinge mills. It is also known that cements 10 and 11 were obtained from one finishing mill before and after, respectively, the addition of new balls, and that samples 12 and 13 were taken in the same way from a second mill. Cements 7 and 8 , which are of the same type and brand, differ by about 1 year in date of manufacture.

\section{PARTICLE SIZE AND COMPOSITION}

Each of the cements was separated into five size-fractions ${ }^{3}$ by means of air elutriation, using in the case of the two fine fractions for all cements except numbers 5 and 6 , air having about 10 -percent relative humidity. Chemical analyses were made on the whole cements and all of the fractions. The results of these analyses, together with the compound compositions as calculated according to the method of Bogue, ${ }^{4}$ are presented in table 1 . The percentages of the whole cements composed of material within the size ranges of each of the different fractions as determined by the Wagner turbidimeter ${ }^{5}$ are also presented.

TABLE 1.-Chemical compositions of whole cements and fractions and compound compositions calculated on ignition-loss basis

\begin{tabular}{|c|c|c|c|c|c|c|c|c|c|c|c|c|c|c|c|}
\hline \multirow[b]{2}{*}{ Cement } & \multirow{2}{*}{$\begin{array}{l}\text { Fraction } \\
\text { size range }\end{array}$} & \multirow{2}{*}{ 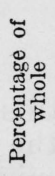 } & \multicolumn{8}{|c|}{ Oxide compositions } & \multicolumn{5}{|c|}{$\begin{array}{l}\text { Calculated compound } \\
\text { compositions }\end{array}$} \\
\hline & & & 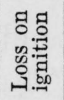 & 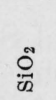 & Oొ & 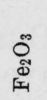 & 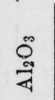 & 品 & ○ீ & 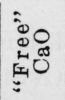 & 粫 & Dू & $\int_{0}^{4}$ & $0^{4}$ & $\begin{array}{l}0 \\
0 \\
\text { Wू } \\
\text { Jే }\end{array}$ \\
\hline & $\left\{\begin{array}{c}\text { Microns } \\
\text { Whole... } \\
0-7 \\
7-22 \\
22-40 \\
40-55 \\
>55\end{array}\right.$ & $\begin{array}{l}\% \\
24 \\
21 \\
22 \\
16 \\
17\end{array}$ & $\begin{array}{l}\% \\
1.0 \\
2.1 \\
.6 \\
.3 \\
.2 \\
.3\end{array}$ & $\begin{array}{c}\% \\
26.4 \\
23.2 \\
26.7 \\
27.8 \\
28.3 \\
28.5 \\
28\end{array}$ & \begin{tabular}{c|}
$\%$ \\
63.2 \\
62.4 \\
64.4 \\
63.9 \\
63.5 \\
63.1
\end{tabular} & $\begin{array}{l}\% \\
1.9 \\
2.0 \\
1.9 \\
1.9 \\
2.0 \\
2.1\end{array}$ & $\begin{array}{c}\% \\
3.3 \\
3.3 \\
3.3 \\
3.2 \\
3.5 \\
3.4\end{array}$ & $\begin{array}{r}\% \\
2.6 \\
2.6 \\
2.5 \\
2.5 \\
2.5 \\
2.5\end{array}$ & $\begin{array}{r}\% \\
1.7 \\
4.4 \\
.8 \\
.4 \\
.3 \\
.2\end{array}$ & $\begin{array}{l}\% \\
0.4 \\
1.6 \\
.4 \\
.1 \\
.1 \\
.0\end{array}$ & $\begin{array}{c}\% \\
27 \\
39 \\
32 \\
24 \\
16 \\
14\end{array}$ & $\begin{array}{l}\% \\
55 \\
37 \\
52 \\
62 \\
69 \\
71\end{array}$ & $\begin{array}{l}\% \\
5.8 \\
6.1 \\
5.7 \\
5.7 \\
6.1 \\
6.3\end{array}$ & $\begin{array}{l}\% \\
5.5 \\
5.4 \\
5.6 \\
5.3 \\
5.9 \\
5.5\end{array}$ & $\begin{array}{l}\% \\
2.9 \\
7.5 \\
1.4 \\
.7 \\
.5 \\
.3\end{array}$ \\
\hline & $\left\{\begin{array}{l}\text { Whole } \\
0-7 \\
7-22 \\
22-40 \\
40-55 \\
>55\end{array}\right.$ & $\begin{array}{l}24 \\
26 \\
17 \\
14 \\
19\end{array}$ & $\begin{array}{r}1.5 \\
2.9 \\
1.2 \\
.6 \\
.5 \\
.5\end{array}$ & $\begin{array}{l}22.2 \\
19.4 \\
23.5 \\
23.6 \\
23.4 \\
23.5\end{array}$ & $\begin{array}{l}59.5 \\
57.1 \\
61.0 \\
61.0 \\
60.6 \\
59.9\end{array}$ & $\begin{array}{l}5.0 \\
5.4 \\
4.5 \\
4.8 \\
5.1 \\
5.2\end{array}$ & $\begin{array}{l}5.3 \\
6.1 \\
4.7 \\
5.2 \\
5.5 \\
5.6\end{array}$ & $\begin{array}{l}3.8 \\
3.7 \\
3.7 \\
3.7 \\
3.9 \\
3.9\end{array}$ & $\begin{array}{r}1.8 \\
4.1 \\
1.1 \\
.5 \\
.5 \\
.5\end{array}$ & $\begin{array}{r}.5 \\
1.5 \\
.6 \\
.3 \\
.1 \\
.3\end{array}$ & $\begin{array}{l}25 \\
25 \\
29 \\
25 \\
24 \\
20\end{array}$ & $\begin{array}{l}45 \\
37 \\
45 \\
49 \\
49 \\
53\end{array}$ & $\begin{array}{l}15.3 \\
16.3 \\
13.8 \\
14.4 \\
15.4 \\
15.9\end{array}$ & $\begin{array}{l}5.5 \\
7.0 \\
4.7 \\
5.8 \\
6.1 \\
5.8\end{array}$ & $\begin{array}{r}3.1 \\
7.0 \\
1.8 \\
.9 \\
.8 \\
.8\end{array}$ \\
\hline
\end{tabular}

2. Lea and Parker, Building Research (England) Technical Paper 16; also, Phil. Trans. Roy. Soc. 234, 1 (1934).

${ }_{3}$ Method of separating described in J. Research NBS 14, 419 (1935) RP777.

Ind. Eng. Chem., Analytical Edition, 1, 192 (1929); also Portland Cement Association Fellowship Paper no. 21.

S Proc. Am. Soc. Testing Materials 33, II, 553 (1933). 
TABLE 1.-Chemical compositions of whole cements and fractions and compound compositions calculated on ignition-loss basis-Continued

\begin{tabular}{|c|c|c|c|c|c|c|c|c|c|c|c|c|c|c|c|}
\hline \multirow[b]{2}{*}{ Cement } & \multirow[b]{2}{*}{$\begin{array}{c}\text { Fruction } \\
\text { size range }\end{array}$} & \multirow{2}{*}{ 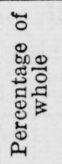 } & \multicolumn{8}{|c|}{ Oxide compositions } & \multicolumn{5}{|c|}{$\begin{array}{l}\text { Calculated compound } \\
\text { compositions }\end{array}$} \\
\hline & & & 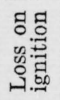 & 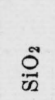 & ర్ల & 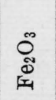 & 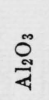 & ${ }_{\substack{\infty \\
\sum_{1}^{\circ}}}$ & $\overbrace{\mathscr{0}}^{\infty}$ & 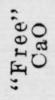 & 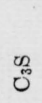 & ర̃ & $\frac{4}{4}$ & $0^{4}$ & $\begin{array}{l}\text { Dే } \\
\text { कू } \\
0\end{array}$ \\
\hline & 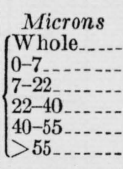 & $\begin{array}{l}\% \\
22 \\
26 \\
25 \\
11 \\
16\end{array}$ & $\begin{array}{l}\% \\
1.0 \\
2.3 \\
.8 \\
.4 \\
.4 \\
.3\end{array}$ & $\begin{array}{l}\% \\
23.4 \\
19.5 \\
24.4 \\
25.2 \\
25.3 \\
24.9\end{array}$ & $\begin{array}{c}\% \\
61.5 \\
59.3 \\
62.5 \\
62.4 \\
62.2 \\
61.6\end{array}$ & $\begin{array}{l}\% \\
5.5 \\
6.4 \\
5.1 \\
4.9 \\
5.3 \\
5.6\end{array}$ & $\begin{array}{l}\% \\
5.4 \\
6.3 \\
4.8 \\
4.7 \\
5.0 \\
5.6\end{array}$ & $\begin{array}{r}\% \\
0.9 \\
.9 \\
.9 \\
.8 \\
.8 \\
.8\end{array}$ & $\begin{array}{l}\% \\
1.8 \\
4.6 \\
.8 \\
.4 \\
.3 \\
.2\end{array}$ & $\begin{array}{l}\% \\
0.8 \\
1.3 \\
.5 \\
.2 \\
.1 \\
.1\end{array}$ & $\begin{array}{l}\% \\
22 \\
28 \\
27 \\
22 \\
18 \\
15\end{array}$ & $\begin{array}{c}\% \\
50 \\
35 \\
49 \\
55 \\
59 \\
60\end{array}$ & $\begin{array}{c}\% \\
16.6 \\
19.4 \\
15.4 \\
14.9 \\
16.1 \\
17.1\end{array}$ & $\begin{array}{l}\% \\
5.1 \\
5.8 \\
4.2 \\
4.3 \\
4.7 \\
5.3\end{array}$ & $\begin{array}{l}\% \\
3.0 \\
7.9 \\
1.4 \\
.7 \\
.5\end{array}$ \\
\hline & $\left\{\begin{array}{l}\text { Whole. } \\
0-7 \\
7-22 \\
22-40 \\
40-55 \\
>55\end{array}\right.$ & $\begin{array}{l}22 \\
31 \\
22 \\
12 \\
13\end{array}$ & $\begin{array}{r}1.2 \\
2.3 \\
.6 \\
.4 \\
.3 \\
.2\end{array}$ & $\begin{array}{l}23.0 \\
19.7 \\
25.0 \\
24.8 \\
24.1 \\
24.1\end{array}$ & & $\begin{array}{l}5.5 \\
6.4 \\
4.5 \\
4.9 \\
5.5 \\
5.7\end{array}$ & $\begin{array}{l}5.4 \\
6.0 \\
4.5 \\
5.1 \\
5.4 \\
5.8\end{array}$ & $\begin{array}{l}3.6 \\
4.1 \\
3.2 \\
3.3 \\
3.6 \\
3.7\end{array}$ & $\begin{array}{l}1.7 \\
4.1 \\
.8 \\
.4 \\
.4 \\
.3\end{array}$ & $\begin{array}{l}.1 \\
.1 \\
.0 \\
.0 \\
.0 \\
.1\end{array}$ & $\begin{array}{l}17 \\
22 \\
18 \\
16 \\
15 \\
11\end{array}$ & $\begin{array}{l}52 \\
40 \\
58 \\
59 \\
58 \\
61\end{array}$ & $\begin{array}{l}16.5 \\
19.4 \\
13.7 \\
15.0 \\
16.9 \\
17.4\end{array}$ & $\begin{array}{l}5.0 \\
5.1 \\
4.3 \\
5.3 \\
5.1 \\
5.8\end{array}$ & $\begin{array}{r}3.0 \\
7.0 \\
1.3 \\
.8 \\
.6\end{array}$ \\
\hline & $\left\{\begin{array}{l}\text { Who } \\
0-7 \\
7-22 \\
22-4 \\
40-5 \\
>55\end{array}\right.$ & $\begin{array}{l}15 \\
25 \\
23 \\
13 \\
24\end{array}$ & $\begin{array}{r}1.3 \\
3.5 \\
4.6 \\
1.5 \\
.6 \\
.6\end{array}$ & $\begin{array}{l}20.6 \\
18.7 \\
20.0 \\
21.0 \\
21.3 \\
21.0\end{array}$ & & $\begin{array}{l}4.6 \\
4.4 \\
4.2 \\
4.6 \\
5.0 \\
5.0\end{array}$ & $\begin{array}{l}5.6 \\
5.0 \\
5.4 \\
6.0 \\
6.1 \\
6.3\end{array}$ & $\begin{array}{l}2.0 \\
1.8 \\
1.9 \\
2.0 \\
1.9 \\
2.0\end{array}$ & $\begin{array}{r}1.5 \\
4.7 \\
1.3 \\
.4 \\
.2 \\
.2\end{array}$ & $\begin{array}{l}.7 \\
.8 \\
.4 \\
.3 \\
.3 \\
.3\end{array}$ & $\begin{array}{l}55 \\
55 \\
57 \\
55 \\
56 \\
55\end{array}$ & $\begin{array}{l}17 \\
12 \\
14 \\
18 \\
19 \\
19\end{array}$ & $\begin{array}{l}13.9 \\
13.4 \\
12.8 \\
13.9 \\
15.2 \\
15.2\end{array}$ & $\begin{array}{l}7.2 \\
5.8 \\
7.2 \\
8.2 \\
7.4 \\
8.3\end{array}$ & $\begin{array}{r}2.5 \\
8.0 \\
2.2 \\
.7 \\
.3\end{array}$ \\
\hline & & $\begin{array}{l}26 \\
29 \\
23 \\
11 \\
11\end{array}$ & $\begin{array}{l}1.0 \\
1.9 \\
1.6 \\
.8 \\
.3 \\
.3\end{array}$ & $\begin{array}{l}21.4 \\
19.6 \\
21.5 \\
22.2 \\
22.4 \\
22.4\end{array}$ & $\begin{array}{l}65.2 \\
63.5 \\
65.4 \\
66.0 \\
66.1 \\
66.0\end{array}$ & & & $\begin{array}{l}2.0 \\
1.9 \\
1.9 \\
1.9 \\
2.0 \\
1.9\end{array}$ & $\begin{array}{r}1.9 \\
4.8 \\
1.4 \\
.5 \\
.3 \\
.2\end{array}$ & $\begin{array}{l}.7 \\
.5 \\
.3 \\
.3 \\
.3 \\
.5\end{array}$ & $\begin{array}{l}52 \\
52 \\
54 \\
53 \\
51 \\
47\end{array}$ & & $\begin{array}{l}7.1 \\
6.9 \\
6.9 \\
7.2 \\
7.6 \\
7.8\end{array}$ & $\begin{array}{l}12.8 \\
12.3 \\
11.9 \\
12.4 \\
13.0 \\
13.4\end{array}$ & $\begin{array}{r}3.2 \\
8.1 \\
2.4 \\
.8 \\
.5\end{array}$ \\
\hline & & $\begin{array}{l}26 \\
24 \\
20 \\
12 \\
18\end{array}$ & $\begin{array}{r}1.0 \\
2.1 \\
.8 \\
.5 \\
.4 \\
.4\end{array}$ & $\begin{array}{l}21.9 \\
18.8 \\
23.0 \\
24.1 \\
23.1 \\
22.3\end{array}$ & $\begin{array}{l}59.3 \\
57.2 \\
60.4 \\
60.8 \\
60.4 \\
59.6\end{array}$ & & & $\begin{array}{l}4.7 \\
5.0 \\
5.0 \\
4.3 \\
4.7 \\
5.3\end{array}$ & $\begin{array}{r}1.6 \\
3.5 \\
.7 \\
.3 \\
.2 \\
.2\end{array}$ & $\begin{array}{l}.3 \\
.1 \\
.0 \\
.0 \\
.0\end{array}$ & $\begin{array}{l}27 \\
30 \\
29 \\
25 \\
28 \\
30\end{array}$ & & $\begin{array}{l}17.3 \\
19.5 \\
15.4 \\
14.7 \\
16.7 \\
18.5\end{array}$ & $\begin{array}{l}4.3 \\
5.1 \\
4.3 \\
4.0 \\
4.0 \\
4.5\end{array}$ & $\begin{array}{r}2.7 \\
6.0 \\
1.2 \\
.5 \\
.3\end{array}$ \\
\hline & & 25 & $\begin{array}{l}1.2 \\
2.6\end{array}$ & & & & & & $\begin{array}{l}1.9 \\
4.7\end{array}$ & $\begin{array}{l}.2 \\
.7\end{array}$ & & & $\begin{array}{l}15.5 \\
14.2\end{array}$ & & $\begin{array}{l}3.2 \\
8.1\end{array}$ \\
\hline & & $\begin{array}{l}26 \\
23 \\
11 \\
15\end{array}$ & $\begin{array}{l}.9 \\
.5 \\
.4 \\
.4\end{array}$ & $\begin{array}{l}23.1 \\
24.6 \\
24.1 \\
23.5\end{array}$ & & & $\begin{array}{l}4.4 \\
4.2 \\
5.1 \\
5.2\end{array}$ & $\begin{array}{l}3.7 \\
3.3 \\
3.6 \\
4.1\end{array}$ & $\begin{array}{r}1.3 \\
.4 \\
.3 \\
.3\end{array}$ & $\begin{array}{l}.4 \\
.1 \\
.1 \\
.0\end{array}$ & $\begin{array}{l}35 \\
30 \\
24 \\
26\end{array}$ & & $\begin{array}{l}14.0 \\
13.7 \\
14.6 \\
16.4\end{array}$ & & $\begin{array}{r}2.2 \\
.8 \\
.5 \\
.5\end{array}$ \\
\hline & & $\begin{array}{l}28 \\
24 \\
21 \\
10 \\
17\end{array}$ & $\begin{array}{r}1.1 \\
2.9 \\
1.0 \\
.6 \\
.4 \\
.4\end{array}$ & $\begin{array}{l}21.6 \\
19.4 \\
22.1 \\
22.7 \\
22.7 \\
22.5\end{array}$ & & $\begin{array}{l}2.0 \\
2.0 \\
2.0 \\
1.9 \\
2.0 \\
2.1\end{array}$ & & $\begin{array}{l}3.4 \\
3.1 \\
3.3 \\
3.4 \\
3.5 \\
3.7\end{array}$ & $\begin{array}{r}1.6 \\
4.0 \\
.8 \\
.4 \\
.2 \\
.2\end{array}$ & $\begin{array}{r}1.0 \\
2.8 \\
.8 \\
.0 \\
.1 \\
.2\end{array}$ & $\begin{array}{l}56 \\
56 \\
56 \\
54 \\
53 \\
48\end{array}$ & & $\begin{array}{l}6.1 \\
6.1 \\
5.9 \\
5.8 \\
5.9 \\
6.3\end{array}$ & $\begin{array}{l}11.1 \\
11.4 \\
11.1 \\
11.4 \\
11.6 \\
12.5\end{array}$ & $\begin{array}{l}2.7 \\
6.8 \\
1.3 \\
. \\
.\end{array}$ \\
\hline & & $\begin{array}{l}19 \\
29 \\
26 \\
13 \\
13\end{array}$ & $\begin{array}{r}1.1 \\
2.7 \\
.9 \\
.5 \\
.4 \\
.4\end{array}$ & $\begin{array}{l}21.2 \\
18.8 \\
21.7 \\
22.6 \\
22.7 \\
22.1\end{array}$ & & $\begin{array}{l}4.3 \\
4.7 \\
4.0 \\
3.9 \\
4.1 \\
4.4\end{array}$ & & $\begin{array}{l}3.6 \\
3.5 \\
3.6 \\
3.5 \\
3.6 \\
3.9\end{array}$ & $\begin{array}{r}1.8 \\
4.6 \\
1.4 \\
.4 \\
.2 \\
.2\end{array}$ & $\begin{array}{l}.1 \\
.6 \\
.2 \\
.1 \\
.0 \\
.0\end{array}$ & $\begin{array}{l}46 \\
43 \\
50 \\
48 \\
44 \\
44\end{array}$ & & $\begin{array}{l}14.3 \\
12.2 \\
11.8 \\
12.4 \\
13.3\end{array}$ & & $\begin{array}{r}3.1 \\
7.8 \\
2.3 \\
.8 \\
.3 \\
.3\end{array}$ \\
\hline & & $\begin{array}{l}20 \\
28 \\
23 \\
15 \\
14\end{array}$ & $\begin{array}{r}1.1 \\
2.6 \\
1.0 \\
.6 \\
.5 \\
.4\end{array}$ & $\begin{array}{l}21.3 \\
18.5 \\
21.5 \\
22.7 \\
22.4 \\
22.1\end{array}$ & & $\begin{array}{l}4.6 \\
5.2 \\
4.4 \\
4.2 \\
4.5 \\
4.9\end{array}$ & & $\begin{array}{l}3.8 \\
3.6 \\
3.8 \\
3.6 \\
3.8 \\
4.0\end{array}$ & $\begin{array}{r}4.5 \\
1.3 \\
.4 \\
.2 \\
.2\end{array}$ & $\begin{array}{l}.4 \\
.7 \\
.2 \\
.1 \\
.2 \\
.1\end{array}$ & $\begin{array}{l}45 \\
43 \\
52 \\
42 \\
43 \\
43\end{array}$ & & & & $\begin{array}{r}3.1 \\
7.6 \\
2.2 \\
.7 \\
.3 \\
.4\end{array}$ \\
\hline 12 & $\left\{\begin{array}{l}\mathrm{b} \\
0- \\
7- \\
22 \\
40 \\
>\end{array}\right.$ & $\begin{array}{l}21 \\
27 \\
24 \\
12 \\
16\end{array}$ & $\begin{array}{r}1.1 \\
2.6 \\
1.0 \\
.6 \\
.4 \\
.4\end{array}$ & $\begin{array}{l}21.2 \\
18.6 \\
21.5 \\
22.6 \\
22.8 \\
22.1\end{array}$ & $\begin{array}{l}62.7 \\
60.0 \\
63.5 \\
64.2 \\
64.0 \\
63.3\end{array}$ & $\begin{array}{l}4.1 \\
4.5 \\
3.9 \\
3.7 \\
4.0 \\
4.2\end{array}$ & $\begin{array}{l}5.5 \\
5.7 \\
5.1 \\
5.3 \\
5.2 \\
5.6\end{array}$ & $\begin{array}{l}3.6 \\
3.5 \\
3.6 \\
3.4 \\
3.7 \\
3.9\end{array}$ & $\begin{array}{r}1.9 \\
4.7 \\
1.5 \\
.6 \\
.2 \\
.3\end{array}$ & $\begin{array}{l}.4 \\
.6 \\
.2 \\
.1 \\
.0 \\
.1\end{array}$ & $\begin{array}{l}46 \\
45 \\
51 \\
46 \\
45 \\
46\end{array}$ & $\begin{array}{l}31 \\
29\end{array}$ & $\begin{array}{l}12.4 \\
13.5 \\
11.8 \\
11.3 \\
12.0 \\
12.8\end{array}$ & $\begin{array}{l}7.6 \\
7.7 \\
6.9 \\
7.7 \\
7.2 \\
7.6\end{array}$ & $\begin{array}{r}3.3 \\
8.0 \\
2.6 \\
.9 \\
.4 \\
.5\end{array}$ \\
\hline & $\left\{\begin{array}{l}y \\
0 \\
7 \\
2 \\
40\end{array}\right.$ & $\begin{array}{l}22 \\
26 \\
24 \\
12 \\
16\end{array}$ & $\begin{array}{r}1.0 \\
2.5 \\
.9 \\
.5 \\
.4 \\
.4\end{array}$ & $\begin{array}{l}21.3 \\
18.4 \\
21.7 \\
22.8 \\
22.8 \\
22.1\end{array}$ & $\begin{array}{l}62.3 \\
59.6 \\
62.8 \\
63.6 \\
63.2 \\
62.7\end{array}$ & $\begin{array}{l}4.7 \\
5.1 \\
4.4 \\
4.2 \\
4.4 \\
4.8\end{array}$ & $\begin{array}{l}5.1 \\
5.5 \\
4.7 \\
4.8 \\
5.0 \\
5.3 \\
\end{array}$ & $\begin{array}{l}3.9 \\
3.6 \\
3.8 \\
3.6 \\
3.7 \\
4.0\end{array}$ & $\begin{array}{r}1.8 \\
4.8 \\
1.4 \\
.4 \\
.2 \\
.2 \\
\end{array}$ & $\begin{array}{l}.4 \\
.5 \\
.2 \\
.1 \\
.1 \\
.2 \\
\end{array}$ & $\begin{array}{l}46 \\
44 \\
44 \\
\end{array}$ & $\begin{array}{l}27 \\
19 \\
25 \\
30 \\
33 \\
30 \\
\end{array}$ & $\begin{array}{l}14.0 \\
15.5 \\
13.4 \\
12.8 \\
13.4 \\
14.6 \\
\end{array}$ & \begin{tabular}{|l|}
5.8 \\
5.9 \\
4.9 \\
5.5 \\
5.8 \\
5.8 \\
\end{tabular} & $\begin{array}{r}3.1 \\
8.2 \\
2.4 \\
.7 \\
.3 \\
.3 \\
\end{array}$ \\
\hline
\end{tabular}


Figures 1 to 4 are schematic diagrams which show pictorially the calculated compound compositions of the cements. There are also shown a series of curves giving the amount of each compound finer than any given size, expressed as the percentage of the whole cement.
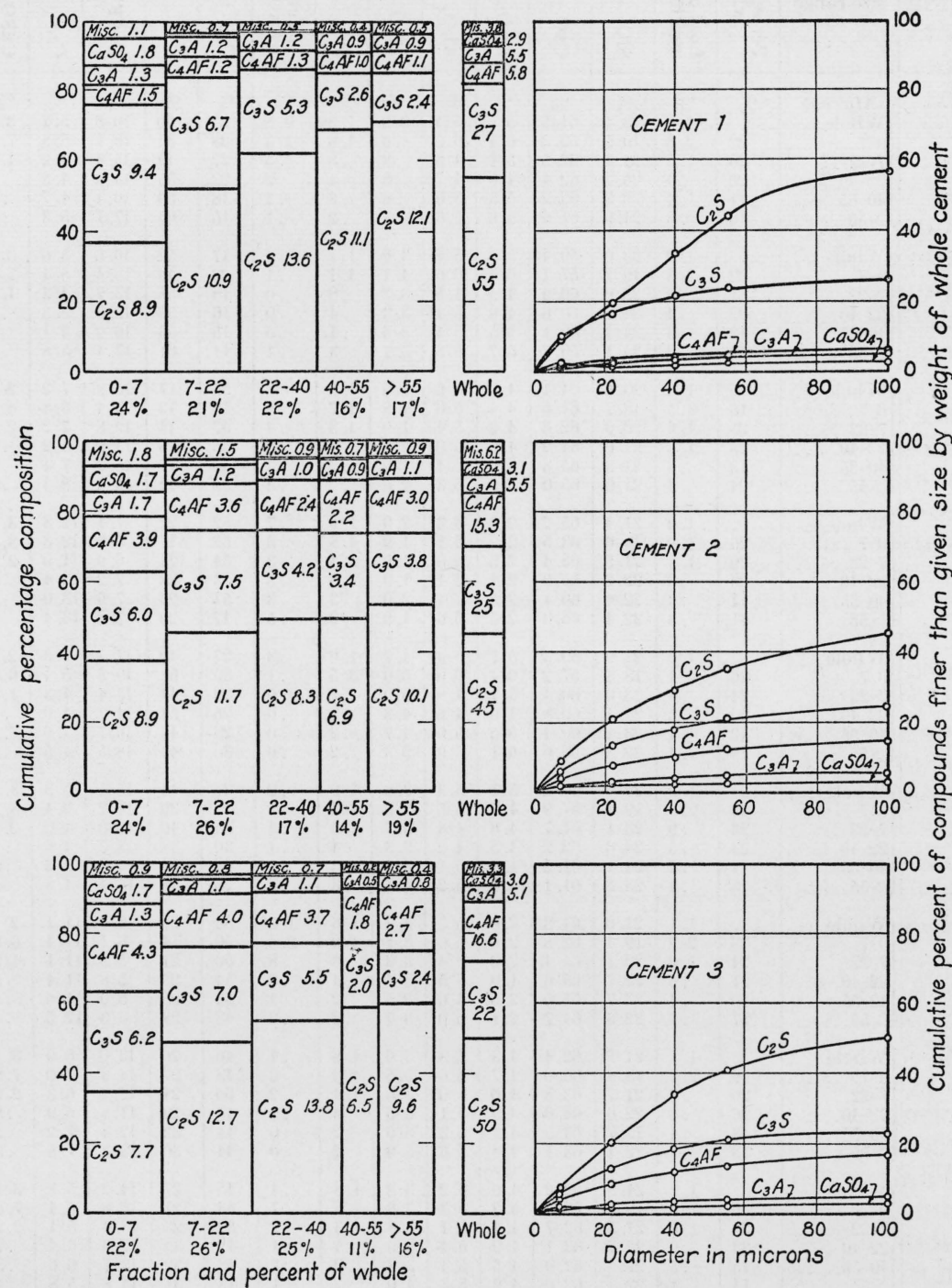

FIGURE 1.-Size distribution of calculated compounds in cements 1, 2, and 3 .

The diagrams on the left can be looked upon as the cross sections of the cements with the particles segregated according to size and composition. The curves on the right show the amounts of each compound finer than any given size, expressed as percentages of the whole cement.

In the schematic diagrams the horizontal spacings are proportional to the percentages, as determined in the turbidimeter, of the whole cements composed of the several fractions, and the vertical spacings are proportional to the percentages of the various compounds con- 
tained by the fractions. The diagram can accordingly be looked upon as a cross section of a cement with the particles segregated according to size and composition. Hence, the area of each small rectangle is in direct proportion to the amount of the particular compound represented which lies between the size limits of the particular fraction. These amounts, expressed as percentages of the whole cements, are printed in each of the rectangles. The graphs on the right are the progressive summations of these percentages plotted against an actual size horizontal scale running from 0 to 100 microns. In preparing these graphs it was assumed that all of the particles were finer than 100 microns, although this was not strictly true, so that the terminal point of each curve corresponds approximately to the percentage of the particular compound in the whole cement. The terminal points of these curves do not always correspond accurately with the analyses of the whole cements, since there is always a certain discrepancy between the granulometric composition as determined by the turbidimeter, and that as determined by air elutriation, because of the continual breaking up of the particles in the elutriation stacks.

Examination of table 1 and the diagrams shows that, in general, the different sizes of particles in a cement differ considerably in chemical composition. Of the four major constituents, the two silicate compounds are the ones which show the greatest variations. The tricalcium silicate $\left(\mathrm{C}_{3} \mathrm{~S}\right)$ tends to be more concentrated in the finer sizes, while the greatest percentages of dicalcium silicate $\left(\mathrm{C}_{2} \mathrm{~S}\right)$ are found in the coarser sizes. This trend is very pronounced in cements 1 to 4 , inclusive. Cement 5 , with a range of only 2 percent in $\mathrm{C}_{3} \mathrm{~S}$ for the different fractions, shows the least variation in this respect. However, the amount of $\mathrm{C}_{2} \mathrm{~S}$ increases considerably from the fine to the coarse material. Cement 6 , although having the greatesi perceutage of $\mathrm{C}_{3} \mathrm{~S}$ in the $7-22$ fraction, followe the general rule quite closely. Of the cements 7 to 13 , inclusive, which were all produced by one manufacturer, only cement 9 follows the general rule exactly. The cements produced at this plant apparently tend to have the greatest percentages of $\mathrm{C}_{2} \mathrm{~S}$ and the least percentages of $\mathrm{C}_{3} \mathrm{~S}$ either in the $22-40$ or the $40-55$ micron fractions rather than in the largest sized fraction. However, they still show the same tendency as the other cements because the percentage of $\mathrm{C}_{2} \mathrm{~S}$ in the $>55$ fraction is in all cases considerably higher than that in the $0-7$, and the greatest percentage of $\mathrm{C}_{3} \mathrm{~S}$ is found in either the $0-7$ or the 7--22 micron fractions in all cements except no. 7 , which has the same percentage of this compound in the $>55$ and $0-7$ fractions.

The tetracalcium alumino-ferrite $\left(\mathrm{C}_{4} \mathrm{AF}\right)$ and the tricalcium aluminate $\left(\mathrm{C}_{3} \mathrm{~A}\right)$ show less definite trends than the silicate compounds. The $\mathrm{C}_{4} \mathrm{AF}$ does show a tendency to be of greatest concentration in either the $0-7$ or the $>55$ fraction, and the least percentage is found in either the 7-22 or the 22-40 micron fractions. Similar irregular trends can be observed in the distribution of the $\mathrm{C}_{3} \mathrm{~A}$. The tendency is for the least percentage of the $\mathrm{C}_{3} \mathrm{~A}$ to be in the 7-22 fraction.

The calcium sulfate is in all cases found largely in the two fine fractions. The percentage of $\mathrm{CaSO}_{4}$ in the 0-7 fraction is usually of the order of twice the sum of the percentages of this compound in the other four fractions. 
The finest fraction further differs from the others in that it usually has a much greater ignition loss. This is true for all the cements except 5 and 6 , no. 5 showing a greater ignition loss in the 7-22 fraction than in the $0-7$, and no. 6 having an ignition loss in the
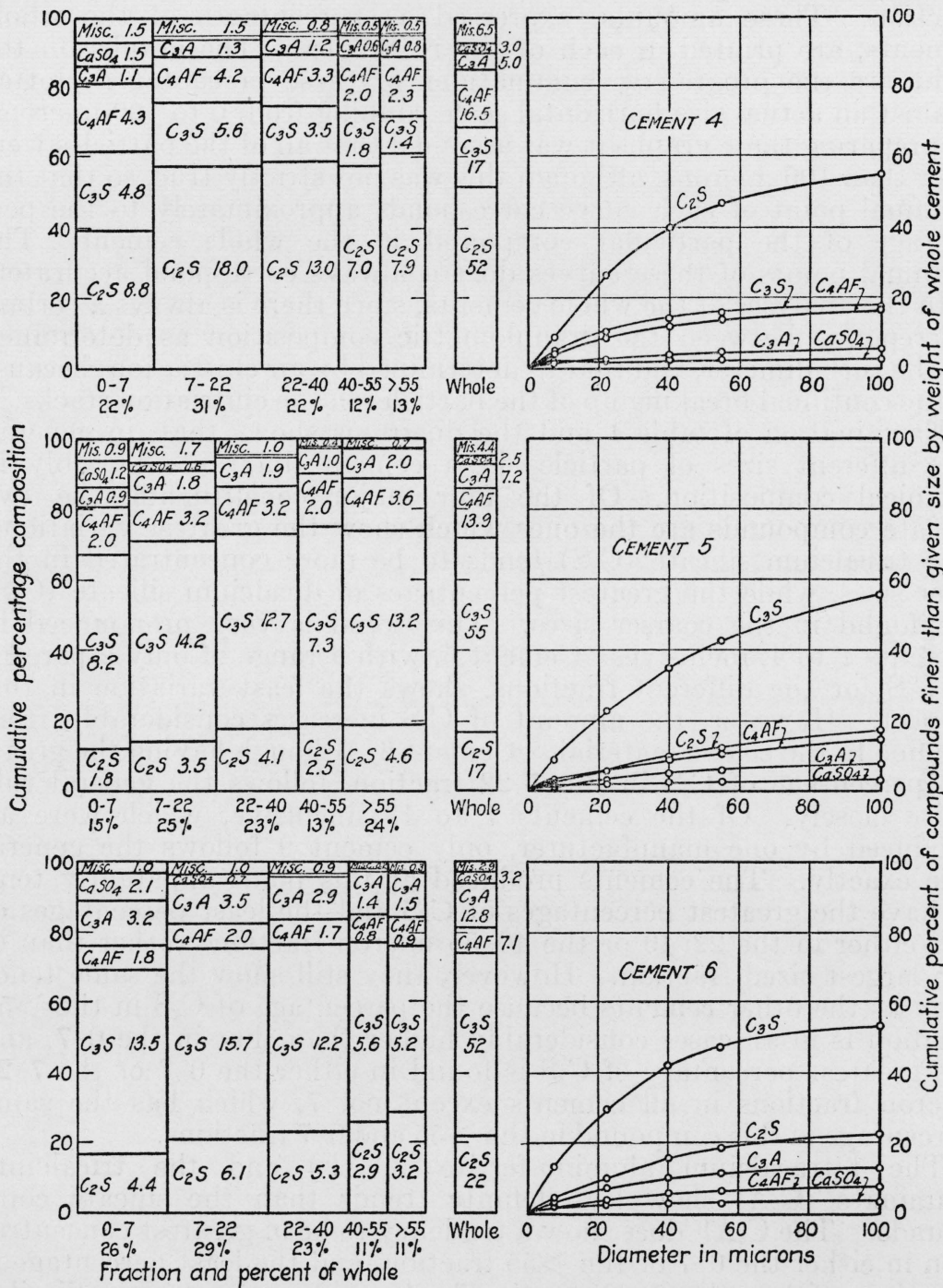

FigURe 2.-Size distribution of calculated compounds in cements 4, 5, and 6.

The diagrams on the left can be looked upon as the cross sections of the cements with the particles segregated according to size and composition. The curves on the right show the amounts of each compound finer than any given size, expressed as percentages of the whole cement.

7-22 fraction almost as great as that in the 0-7. These two cements are exceptions because during their separation the system for drying the air in the elutriation stacks was not in operation. As a result, a considerable amount of hydration occurred during the separation. In separating the other cements the relative humidity of the circu- 
lating air in the stacks was kept down to about 10 percent, so that very little hydration took place. This can be seen by comparing the ignition losses in the whole cements with those in the fractions. With the exception of cements 5 and 6 , therefore, the ignition losses
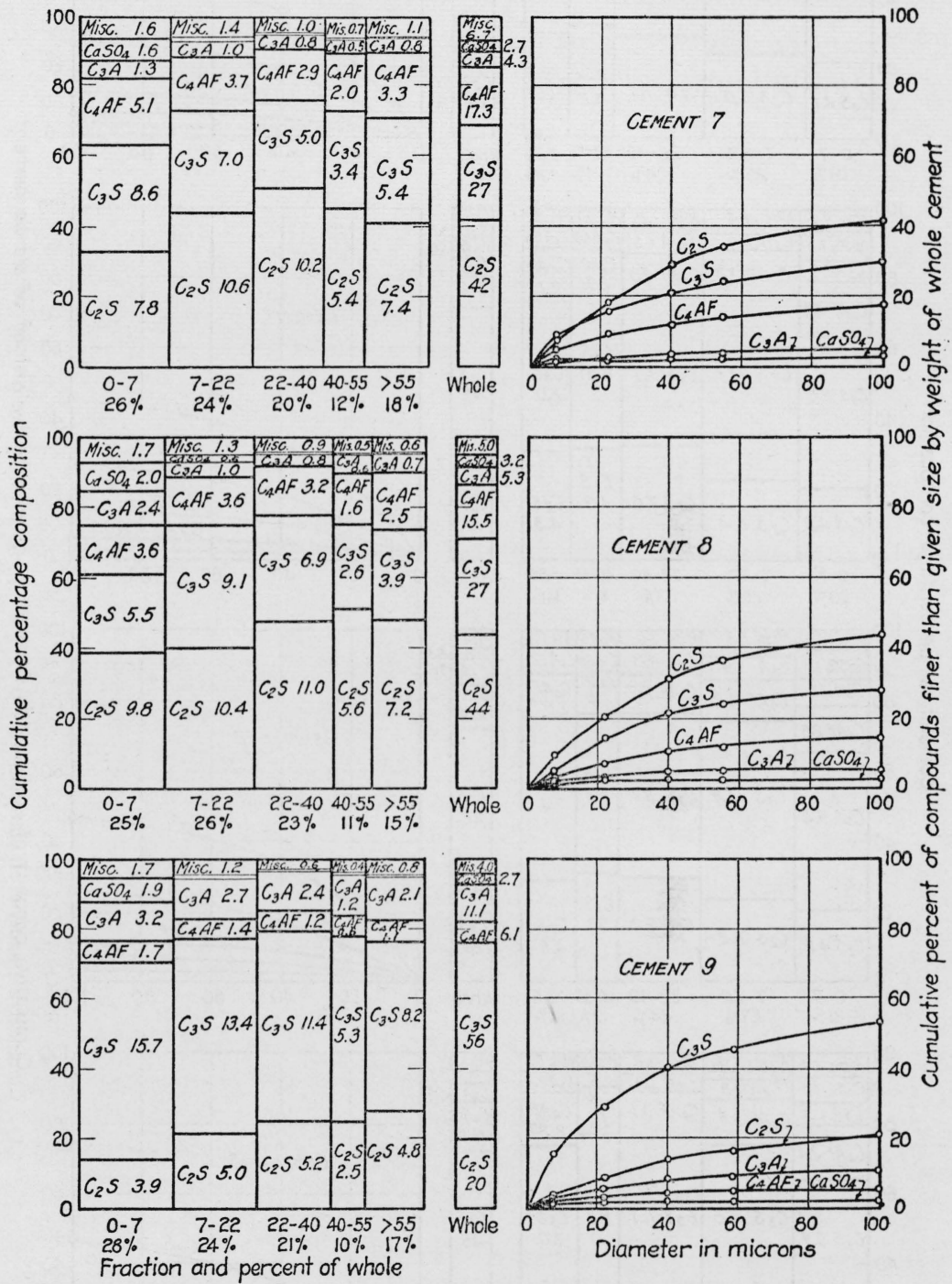

Figure 3.-Size distribution of calculated compounds in cements 7,8 , and 9.

The diagrams on the left can be looked upon as the cross sections of the cements with the particles segregated according to size and composition. The curves on the right show the amounts of each compound finer than any given size, expressed as percentages of the whole cement.

of the various fractions indicate the relative amounts of hydration of the various sizes in the whole cements. It is natural that the fine fraction should contain the most hydrated material since this fraction has a much greater surface area than any of the others exposed to hydration. 

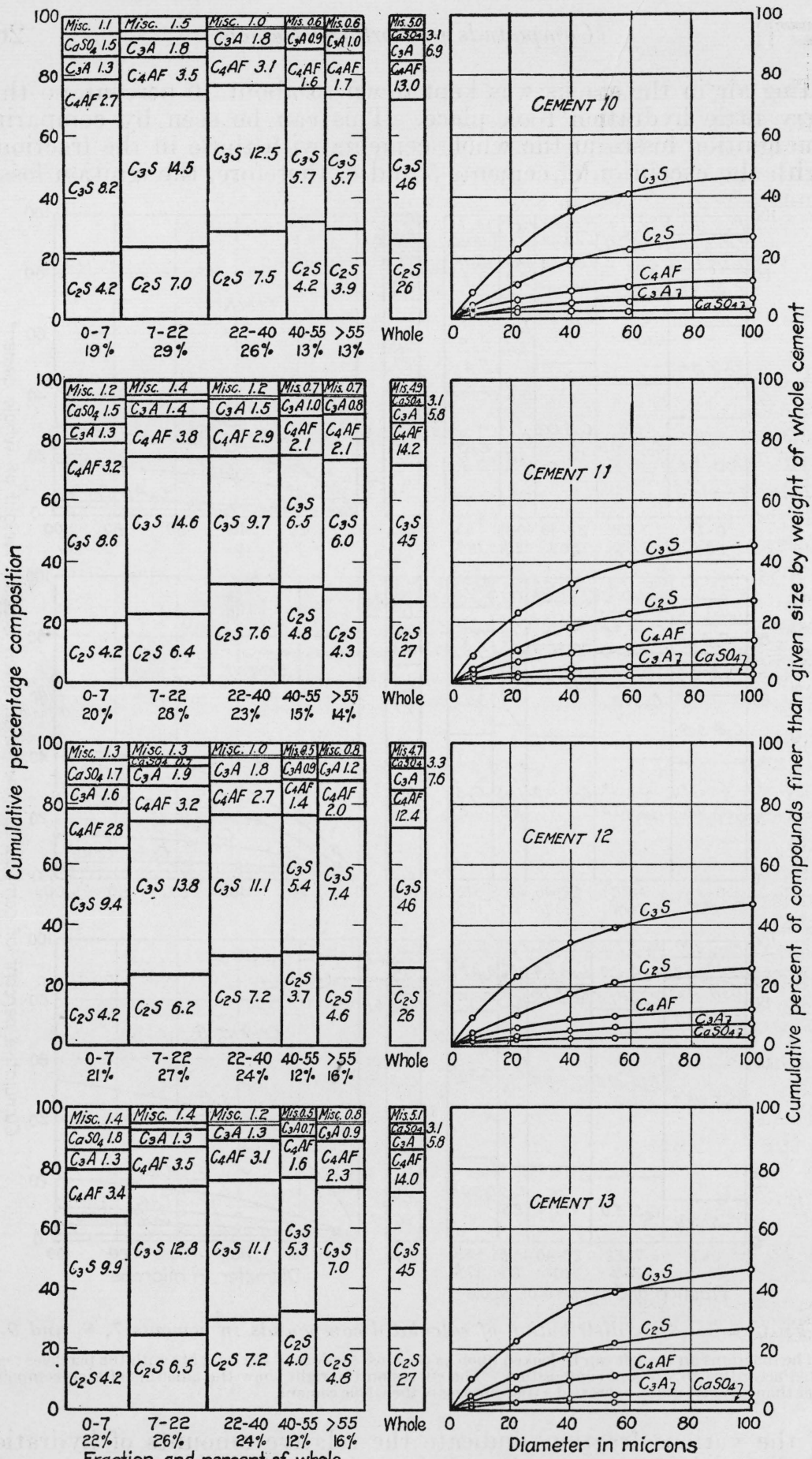

FIGURE 4.-Size distribution of calculated compounds in cements 10,11, 12, and 13.

The diagrams on the left can be looked upon as the cross sections of the cements with the particles segregated according to size and composition. The curves on the right show the amounts of each compound finer than any given size, expressed as percentages of the whole cement. 
The $\mathrm{MgO}$ content of the different fractions does not show very large variations for the majority of the cements. In five of the cements it remains practically constant. Cements 7 to 13 show slight variations in $\mathrm{MgO}$ with the greatest percentage in all seven cements being found in the $>55$ fraction.

\section{HEATS OF HYDRATION OF SIZE FRACTIONS}

\section{GENERAL DETAILS}

A considerable amount of data ${ }^{6}$ on heat of hydration and strength was available for 5 of the 13 cements before the study of their sizefractions was undertaken. These data showed that although four of the five cements were of very similar chemical composition, they had markedly different strengths and heats of hydration. It was believed that some of the difficulty found in trying to explain the behaviors of the whole cements on the basis of their chemical compositions might be the result of the unequal size distributions of the chemical constituents, and, hence, that better correlations might be obtained if the properties of definite size-fractions were studied. The heats of hydration were therefore determined for most of the fractions of these same five cements, nos. 1, 2, 3, 4, and 7 in table 1 .

The determinations of heat of hydration were made by the heat of solution method, using an isothermal calorimeter ${ }^{7}$ at the ages of 3,7 , and 28 days. The data obtained are presented in table 2 . No 3-day determinations were made for the two coarser fractions, since these fractions showed but very little hydration at this age. The heats of hydration of the $>55$ fraction were not determined for cements 1 and 7 . The fractions were all hydrated with 45 percent of mixing water, by weight of the dry material. The 0-7 fraction was also hydrated with 60 percent of mixing water, which produced a paste of about the same consistency as that obtained when 45 percent of water was added to any of the other fractions. With only 45 percent of water the paste made from the 0-7 fraction was quite stiff. The 7-22 fraction of cements $1,2,3$, and 4 was hydrated as obtained in the separation, and also after a sufficient quantity of gypsum had been added to make the $\mathrm{SO}_{3}$ content the same as that of the 0-7 fraction of the same cement. The storage temperature for the hydration of the fractions was maintained at $70 \pm 3^{\circ} \mathrm{F}$. The heats of hydration of the whole cements, when hydrated with 40 percent of water and stored at $70^{\circ} \mathrm{F}$ for the first 24 hours and $100^{\circ} \mathrm{F}$ for the remainder of the hydration period, for the ages 7 and 28 days, were available and are included in the table.

\footnotetext{
- Unpublished data obtained at this Bureau.

7 Similar to the one used in testing the Boulder Dam cements and described in Bureau of Reclamation Specification 566.
} 
TABLE 2.-Heats of hydration at $70^{\circ} \mathbf{F}$. of size-fractions obtained from five cements

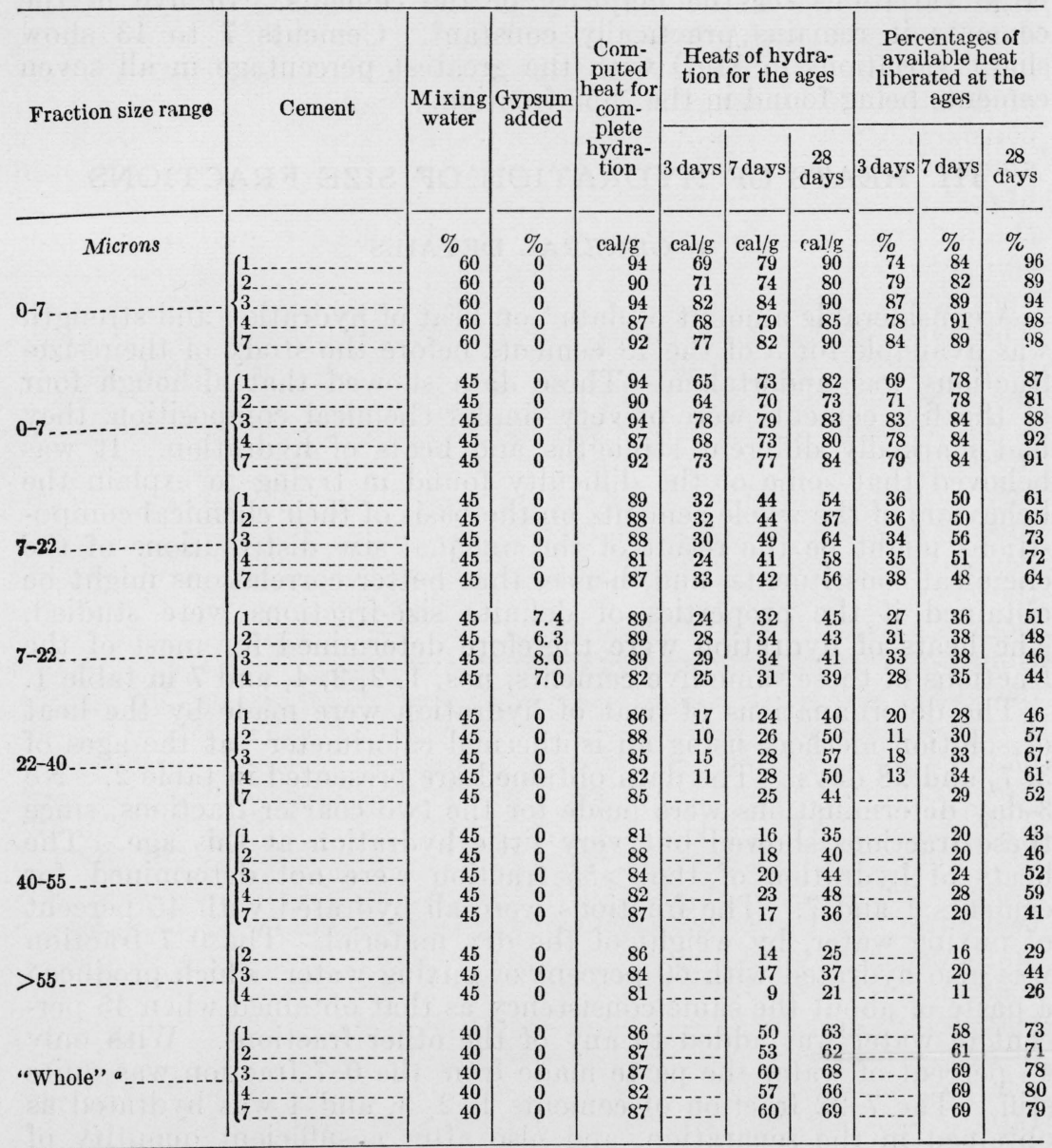

a Hydrated at $70^{\circ} \mathrm{F}$. for first 24 hours and $100^{\circ} \mathrm{F}$. for remainder of period.

The heats available upon complete hydration of the fractions and also of the cements have been calculated from the compound compositions according to the method of Lerch and Bogue ${ }^{8}$, using the values given by them for the heat liberated upon complete hydration of the individual compounds. The calculated heats of complete hydration and the experimentally determined heats of hydration, expressed as percentages of the total heat available, are included in table 2.

\section{DISCUSSION OF RESULTS}

The heat of hydration data for the fractions show that the amounts of heat liberated decrease regularly at all of the ages as the grain sizes of the fractions increase. This would be expected since the smaller surface areas present less opportunity for hydration. The

- BSJ. Research 12, 645(1934) RP684. 
same trends were shown by the heats of hydration of the fractions studied by Lerch and Bogue. ${ }^{9}$ The most striking feature about the data obtained in this study is the large unexplained decrease in the heat of hydration of the 7-22 fraction brought about by the addition of gypsum. The magnitude of this decrease at 7 and 28 days is considerably in excess of that which should have resulted if the same amount of some inert material had been added. Since the heat liberated upon the formation of the additional sulfo-aluminates in the material containing the added gypsum should very nearly have compensated for that of the cement displaced by the gypsum, only very small changes in the heat liberated might have been expected. This is shown by the near equality of the calculated heats available upon complete hydration for each of the cements with and without the gypsum.

An attempt to correlate some of the heats of hydration of the individual fractions with the compound compositions did not prove any more successful than the previous attempts at correlation of the properties of the whole cements with the compositions of the cements. Several equations were derived by the method of least squares giving the heats of hydration of one size-fraction for one age as linear functions of the four major compounds. However, none of these equations were found to yield very good correlations, and the constants derived did not appear to be such as to have any physical significance. For example, the equation derived for the 28-day heat of hydration of the 22-40 fraction was: Heat of hydration (cal $/ \mathrm{g})=0.129 \times \%$ of $\mathrm{C}_{3} \mathrm{~S}+0.385 \times \%$ of $\mathrm{C}_{2} \mathrm{~S}+1.552 \times \%$ of $\mathrm{C}_{4} \mathrm{AF}+0.811 \times \%$ of $\mathrm{C}_{3} \mathrm{~A}$. The heats of hydration as calculated from this equation were 40,49 , 51,52 , and 49 , as compared with the experimentally determined values of $40,50,57,50$, and 44 calories per gram, respectively. With two out of the five cements showing differences between the observed and calculated values of five calories or more, this correlation could scarcely be considered good. Also, the coefficients for the different compounds are obviously not such as to indicate the relative amounts of heat evolved by these compounds. The $\mathrm{C}_{3} \mathrm{~A}$ should probably have a larger coefficient than the silicate compounds, since it hydrates more rapidly and with a greater evolution of heat, but the coefficient for the $\mathrm{C}_{3} \mathrm{~S}$ appears much too low in comparison and that of the $\mathrm{C}_{4} \mathrm{AF}$ too high. The coefficient for the $\mathrm{C}_{3} \mathrm{~S}$ should at least be greater than that of the $\mathrm{C}_{2} \mathrm{~S}$, since its heat of hydration is greater and since it is known to hydrate at a more rapid rate. The results of this study therefore indicated that the explanation of the poor correlation between the chemical compositions and the physical properties of these cements is not to be found entirely in the unequal size distributions of the chemical compounds

The only remaining possibility is that the clinkers from which these cements were made had fundamental differences aside from those shown by the chemical analyses or the calculated compound compositions. It is possible that some of the observed discrepancies were caused by differences in extent of crystallization brought about by differences in the cooling of the clinkers during manufacture. Such effects have recently been pointed out by Lea and Parker. ${ }^{10}$

- See footnote 8 .

10 Building Research (England) Technical Paper 16. 
The method for calculating compound composition suggested by Bogue in $1929^{11}$ made use of the assumption of complete equilibrium crystallization of the compounds in the clinker except as corrected for uncombined lime and silica. It was recognized that such an assumption probably was not strictly correct and would be variable in different clinkers; but as no method was available for estimating the extent of crystallization of the erstwhile liquid, the assumption was justified as the only possible premise until such time as new information should provide opportunity for modification and higher precision.

\section{ACCURACY OF CALCULATED COMPOUND COMPOSI- TIONS AS INDICATED BY OTHER METHODS}

\section{STUDIES OF HEATS OF SOLUTION}

In order to obtain some indication of the reliability of the calculated compound compositions of these five cements, a study was made of their heats of solution. The heat of solution of a cement should theoretically be equal to the sum of the heats of solution of the individual compounds in the relative proportions in which they occur. Furthermore, calorimetric measurements may be made with relative precision. The heats of solution of cements, as well as those for the pure compounds, can be determined within a probable error of about $0.3 \mathrm{cal} / \mathrm{g}$ for a single observation with the apparatus used. Therefore, if the true compound composition of a cement were known, it should be readily possible to obtain agreement within $1 \mathrm{cal} / \mathrm{g}$ between the observed and calculated heats of solution.

The heats of solution of the pure compounds in the acid mixture used (648.5 g of $2.5 \pm .002 N$ nitric acid, $11.5 \mathrm{~g}$ of 48-percent hydrofluoric acid) are given in table 3 . The observed and calculated heats of solution for the whole cements and the fractions are presented in table 4. No allowance was made for the presence of the calcium sulfate in making the calculations because of the uncertainty as to the form in which this compound occurred. It was also known that this compound has a very low heat of solution and could have only a negligible effect, except possibly in the case of the $0-7$ fraction.

TABLE 3.-Heats of solution of pure compounds

\begin{tabular}{|c|c|}
\hline Compound & $\begin{array}{c}\text { Heat of } \\
\text { solution }\end{array}$ \\
\cline { 2 - 2 } & cal/g \\
$\mathrm{C}_{3} \mathrm{~S}$ & 631 \\
$\mathrm{C}_{2} \mathrm{~S}$ & 562 \\
$\mathrm{C}_{4} \mathrm{AF}$ & 582 \\
$\mathrm{C}_{3} \mathrm{~A}$ & 797 \\
$\mathrm{MgO}$ & 875 \\
\hline
\end{tabular}

$\overline{11}$ Ind. Eng. Chem., Analytical Edition, 1, 192(1929); also Portland Cement Association Fellowship Paper 
TABLE 4.-Observed and calculated heats of solution of whole cements and sizefractions

\begin{tabular}{|c|c|c|c|c|c|c|c|}
\hline \multirow{2}{*}{ Cement } & \multirow{2}{*}{ Value } & \multicolumn{6}{|c|}{ Heats of solution (cal/g) and their differences for fractions } \\
\hline & & "Whole" & $0-7 \mu$ & $7-22 \mu$ & $22-40 \mu$ & $40-55 \mu$ & $>55 \mu$ \\
\hline & $\left\{\begin{array}{l}\text { Observed } \\
\text { Calculated_................ } \\
\text { Difference. }\end{array}\right.$ & $\begin{array}{l}585 \\
580 \\
+5\end{array}$ & $\begin{array}{r}555 \\
555 \\
0\end{array}$ & $\begin{array}{l}598 \\
594 \\
+4\end{array}$ & $\begin{array}{r}598 \\
597 \\
+1\end{array}$ & $\begin{array}{r}595 \\
593 \\
+2\end{array}$ & 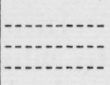 \\
\hline & $\left\{\begin{array}{l}\text { Observed } \\
\text { Calculated } \\
\text { Difference................ }\end{array}\right.$ & $\begin{array}{r}587 \\
577 \\
+10\end{array}$ & $\begin{array}{l}547 \\
549 \\
-2\end{array}$ & $\begin{array}{l}595 \\
586 \\
+9\end{array}$ & $\begin{array}{l}604 \\
596 \\
+8\end{array}$ & $\begin{array}{l}606 \\
599 \\
+7\end{array}$ & $\begin{array}{r}601 \\
597 \\
+4\end{array}$ \\
\hline & 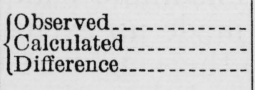 & $\begin{array}{r}582 \\
565 \\
+17\end{array}$ & $\begin{array}{l}548 \\
540 \\
+8\end{array}$ & $\begin{array}{r}592 \\
577 \\
+15\end{array}$ & $\begin{array}{r}592 \\
576 \\
+16\end{array}$ & $\begin{array}{l}592 \\
583 \\
+9\end{array}$ & $\begin{array}{r}596 \\
581 \\
+15\end{array}$ \\
\hline & $\left\{\begin{array}{l}\text { Observed } \\
\text { Calculated.......... } \\
\text { Difference_- }\end{array}\right.$ & $\begin{array}{r}583 \\
567 \\
+16\end{array}$ & $\begin{array}{l}551 \\
553 \\
-2\end{array}$ & $\begin{array}{r}593 \\
582 \\
+11\end{array}$ & $\begin{array}{r}598 \\
591 \\
+7\end{array}$ & $\begin{array}{r}601 \\
591 \\
+10\end{array}$ & $\begin{array}{r}596 \\
592 \\
+4\end{array}$ \\
\hline & 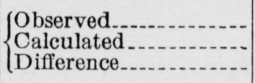 & $\begin{array}{r}594 \\
582 \\
+12\end{array}$ & $\begin{array}{r}561 \\
573 \\
-12\end{array}$ & $\begin{array}{l}605 \\
598 \\
+7\end{array}$ & $\begin{array}{l}604 \\
599 \\
+5\end{array}$ & $\begin{array}{l}604 \\
600 \\
+4\end{array}$ & (-n \\
\hline
\end{tabular}

It is believed that most of the differences between the observed and calculated heats of solution shown in table 4 are sufficiently pronounced to indicate a real significance. Although there is a considerable variation between the differences for the various fractions of any one cement, when the different cements are compared it is seen that they show rather distinct individual trends. The agreement between the observed and calculated values for cement 1 would indicate that the true compound composition was very nearly given by the Bogue method of calculation. In the case of cement 2 , where the differences are nearly the same for the whole cement and two of the fractions, a systematic deviation of the true composition from the calculated composition is indicated. Cement 3, which shows the greatest deviations between the observed and calculated values, would seem to be of a composition considerably different from that obtained by the calculation. In the same way, the larger observed than calculated values of cements 4 and 7 , for all but the $0-7$ fraction, suggest proportionate disagreements between the true and calculated compositions.

The results for the 0-7 fraction do not follow the trends for the other fractions and the whole cements. For three of the cements the calculated value is greater than the observed. The relatively low observed heat of solution as compared with that calculated for this fraction is probably the result of partial hydration, and since the extent of this hydration is unknown, much significance cannot be attached to the heat of solution data for this fraction as an indication of the chemical composition.

According to the theory of Lea and Parker, ${ }^{12}$ the true compositions of cements $2,3,4$, and 7 should be those given by the Bogue calculation unless glass had been formed in the clinker. These cements all have alumina-iron oxide ratios which fall within the range given by these investigators for independent crystallization, wherein the Bogue values should hold without correction, and in the case of cement 1 this ratio is just slightly over the 1.7 limiting maximum. According

12 Building Research (England) Technical Paper 16. 
to this theory, therefore, it would seem that the deviations of the true compound compositions from the calculated compositions, indicated for some of the cements by this heat of solution study, would have to be explained on the basis that glass had been formed during the cooling of the clinker.

\section{MICROSCOPIC ANALYSES}

In order to determine if these clinkers did contain glass and, if so, to what extent, microscopic examinations ${ }^{13}$ were made of polished etched sections prepared from samples of clinker. Quantitative estimates were made of four constituents identified as $\mathrm{C}_{3} \mathrm{~S}, \mathrm{C}_{2} \mathrm{~S}, \mathrm{C}_{4} \mathrm{AF}$, and glass. The $\mathrm{C}_{3} \mathrm{~A}$ was not identified. The minor compounds were ignored and the clinkers considered to be made up exclusively of the four constituents. The results, reduced to the weight basis, are given in table 5. The calculated probable error of the values for the silicate compounds is approximately 1.5 and that of the other two constituents about 0.8 .

TABLE 5.-Quantitative microscopic analysis of cement clinkers

\begin{tabular}{|c|c|c|c|c|c|}
\hline \multirow{2}{*}{ Cement } & $\begin{array}{c}\text { Number } \\
\text { of sections } \\
\text { examined }\end{array}$ & \multicolumn{3}{|c|}{ Average compound composition } \\
\cline { 3 - 6 } & & $\mathrm{C}_{3} \mathrm{~S}$ & $\mathrm{C}_{2} \mathrm{~S}$ & $\mathrm{C}_{4} \mathrm{AF}$ & Glass \\
\hline & & & & & \\
\hline & & Percent & Percent & Percent & Percent \\
1 & 7 & 34 & 54 & 10 & 2 \\
2 & 7 & 33 & 46 & 15 & 6 \\
3 & 7 & 29 & 48 & 18 & 5 \\
4 & 3 & 29 & 47 & 23 & 1 \\
7 & 11 & 36 & 39 & 22 & 3 \\
\hline
\end{tabular}

In table 6 are given, for comparison, the compound compositions of the cements calculated by the Bogue method and the microscopic analyses reduced to the cement basis by allowing for the presence of the minor constituents of the cements. The results obtained by the microscopic method indicate that the $\mathrm{C}_{3} \mathrm{~S}$ content is higher and the $\mathrm{C}_{2} \mathrm{~S}$ content lower than the calculated values in all cases. For three of the five cements, the $\mathrm{C}_{4} \mathrm{AF}$ content is considerably higher by the microscopic method than as calculated.

TABLE 6.-Microscopic analysis of clinkers reduced to cement basis, and calculated compositions of cements

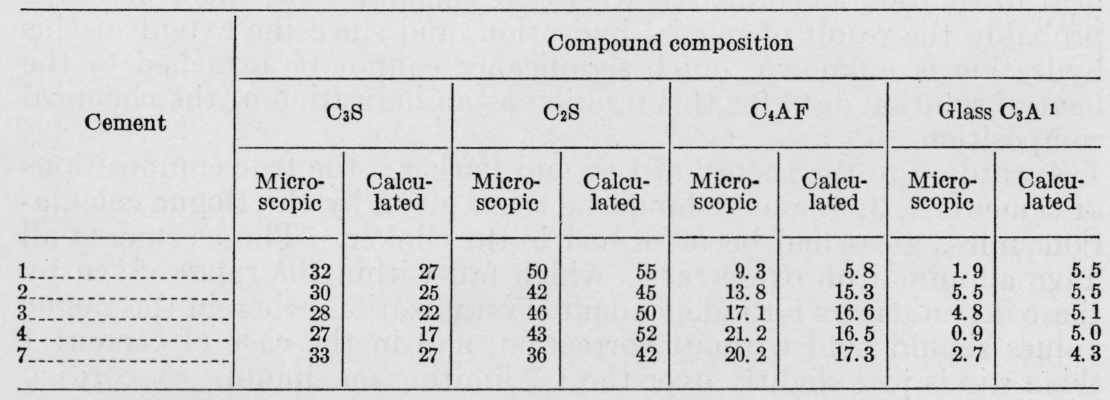

${ }^{1} \mathrm{C}_{3} \mathrm{~A}$ not noted petrographically.

${ }_{13}$ This work was carried out by Dr. H. Insley of this Bureau. A more detailed account of the work, together with data obtained on other clinkers, will be contained in a future report. 
In order to obtain a further comparison between the two methods, the heats of solution were calculated from the microscopic data as reduced to the cement basis. The heat of solution of the glass was not known, but was assumed to be the same as that of the $\mathrm{C}_{3} \mathrm{~A}$. Since the glass content was not large, this approximation should not introduce serious error. The values obtained, together with the observed heats of solution of the cements, are presented in table 7 .

TABLE 7.-Comparison of observed heats of solution with heats of solution calculated from microscopic analyses

\begin{tabular}{|c|c|c|c|}
\hline \multirow{2}{*}{ Cement } & \multicolumn{3}{|c|}{ Heats of solution } \\
\hline & Observed & Calculated & Difference \\
\hline $\begin{array}{l}1 \\
2 \\
3 \\
4 \\
7\end{array}$ & $\begin{array}{c}\mathrm{cal} / \mathrm{g} \\
585 \\
587 \\
582 \\
583 \\
594\end{array}$ & $\begin{array}{c}\mathrm{cal} / \mathrm{g} \\
575 \\
583 \\
581 \\
574 \\
591\end{array}$ & $\begin{array}{c}\mathrm{cal} / \mathrm{g} \\
10 \\
4 \\
1 \\
9 \\
3\end{array}$ \\
\hline
\end{tabular}

In four out of the five cases better agreement is found between the experimentally determined heats of solution and those calculated from the microscopic data than was obtained between the observed heats of solution and those calculated from the Bogue compositions. The results would indicate that the true compositions of the cements were more nearly equal to those determined microscopically than to those calculated by the Bogue method. However, too much weight should not be given to this comparison, since the heats of solution were not determined for the clinkers, and the cements for which they were determined may have been made from clinkers of slightly different composition.

In considering all of the data which would indicate the accuracy of the calculated compositions, it should be borne in mind that four of the five cements were of very similar oxide compositions. These data, therefore, do not necessarily indicate that the Bogue method of calculation is invalid for other cements. Rather, it confirms the opinions held by Bogue, Lerch, Lea and Parker, Bates, Woods, and other investigators that equilibrium crystallization may not in all clinkers be complete, but that an incomplete crystallization, with resultant changes in the compound composition, may have a significant effect upon the properties of the cement.

\section{SUMMARY}

Thirteen cements were separated into the five nominally sized fractions $0-7,7-22,22-40,40-55$, and $>55$ microns, and chemical analyses were made on the fractions and on the whole cements. The compound compositions were calculated according to the method of Bogue. Heats of hydration were determined for the fractions of five of the cements at the ages 3,7 , and 28 days. The compound compositions of the clinkers of these five cements were estimated from sections with a microscope.

On the basis of the calculated compound compositions the greatest percentages of tricalcium silicate appeared in the finer particles, 
while the dicalcium silicate tended to be more concentrated in the coarser particles. The tricalcium aluminate and the tetracalcium alumino-ferrite were about equally distributed between the fine and coarse particles.

No satisfactory correlations were found between the calculated compositions and the heats of hydration.

The addition of about 7 percent of gypsum to the 7-22 micron fraction caused a greater reduction in the heat of hydration than would have been brought about by the addition of a like quantity of some inert material.

The observed heats of solution of five of the cements and those calculated from the Bogue compound compositions, using the heats of solution of the pure compounds, showed quite large differences for some of the cements, thus possibly indicating disagreement between the actual compound composition and that calculated by the Bogue method.

Quantitative estimates obtained with a microscope indicated that the tricalcium silicate was higher and the dicalcium silicate lower than the quantities indicated by the calculation from the oxide compositions. The tricalcium aluminate was not identified petrographically, although glass was found to be present.

The heats of solution of the cements calculated from the compound compositions as estimated microscopically were closer to the observed values than those calculated from the compound compositions computed by the method of Bogue.

Acknowledgment is made to $\mathrm{P}$. H. Bates for originally suggesting this study and for suggestions offered during its progress. In determining the heats of hydration the authors were assisted by $\mathrm{F}$. B. Hornibrook.

Washington, June 12, 1936. 